\title{
Serpinema- (Nematoda: Camallanidae) parasitering van die varswaterskilpad Rhinoclemmys punctularia uit Frans-Guiana
}

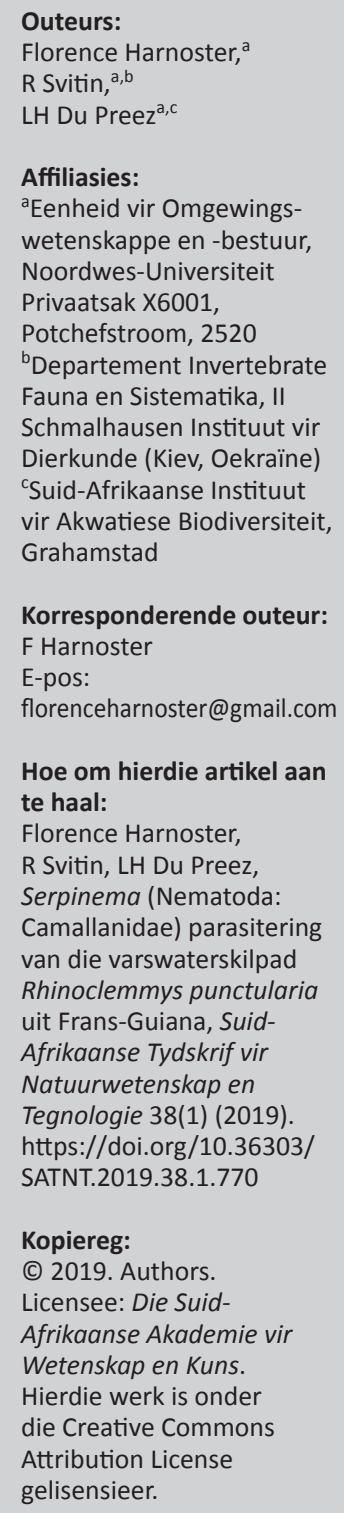

Korresponderende outeur: F Harnoster

E-pos:

florenceharnoster@gmail.com

Hoe om hierdie artikel aan te haal:

Florence Harnoster,

R Svitin, LH Du Preez,

Serpinema (Nematoda:

Camallanidae) parasitering

van die varswaterskilpad

Rhinoclemmys punctularia

uit Frans-Guiana, Suid-

Afrikaanse Tydskrif vir

Natuurwetenskap en

Tegnologie 38(1) (2019).

https://doi.org/10.36303/

SATNT.2019.38.1.770

Kopiereg:

(C) 2019. Authors

Licensee: Die Suid-

Afrikaanse Akademie vir

Wetenskap en Kuns.

Hierdie werk is onder

die Creative Commons

Attribution License

gelisensieer.

\begin{abstract}
Serpinema (Nematoda: Camallanidae) parasitising of the freshwater turtle Rhinoclemmys punctularia from French Guiana: Nematodes of the genus Serpinema belong to the family Camallanidae, the globally distributed parasites of aquatic cold-blooded vertebrates. Hitherto, representatives of Serpinema were found in terrapins from the Americas. Upon studying material from Rhinoclemmys punctularia from French Guiana, we confirmed the novel species status with molecular and morphological techniques.
\end{abstract}

Een van die grootste groepe rondewurms wat diere parasiteer behoort aan die familie Camallanidae. Nematode van hierdie groep kom wêreldwyd voor en bewoon die spysverteringskanale van mariene en varswatervisse, amfibieë en reptiele (hoofsaaklik varswaterskilpaaie) (Yeh 1960; Baker 1987). As gevolg van 'n gebrek aan betroubare morfologiese karakterisering en molekulêre data is die taksonomie van 'n aantal genera in die familie Camallanidae steeds onder verdenking, veral Serpinema.

Hoewel dit mag voorkom of die genus Camallanus sinoniem met Serpinema is, parasiteer die laasgenoemde spesies uitsluitlik varswaterskilpaaie (Baker 1987; Martinez-Silvestre et al 2015). Verteenwoordigers van Serpinema deel gemeenskaplike morfologiese eienskappe met Camallanus-spesies, soos dat beide manlike en vroulike individue 'n goed ontwikkelde bukkalekapsule aan die voorkant van die liggaam het. Daar is tans nege spesies van die genus wat vanuit varswaterskilpaaie beskryf is en nog geldig is (Baker 1987; Martinez-Silvestre et al 2015).

Die doel van hierdie projek is om die morfologie van 'n nuwe Serpinema-spesie van die gasheerspesie Rhinoclemmys punctularia, te karakteriseer. Meer spesifiek beoog die studie om die filogenetiese posisie van die spesie deur molekulêre metodes te bepaal en om morfometriese inligting oor die genus te benut om spesie-identiteit te bepaal.

Die betrokke Serpinema-spesie is in April 2012 by Cayenne in Frans-Guiana ingesamel en in $70 \%$ etanol gestoor. Vir morfometrie is metings van die spesies se kenmerkende eienskappe onder'n Nikon 800-ligmikroskoop gedoen. Middelfragmente van die liggaam is vir molekulêre analises gebruik om die taksonomies-informatiewe liggaamsdele te identifiseer. DNS is met behulp van die KAPA Express Extraction-stel DKAPKK7103 onttrek. Die DNS-volgorde van die geamplifiseerde 28S amplikons is bepaal, bymekaargevoeg deur Geneious-sagteware en die volledige basisvolgordes aan GenBank voorgelê.

Die Serpinema-spesie toon duidelike morfologiese differensiasie van die ander spesies in die familie en genus. Duidelike filogenetiese verskille is ook waargeneem. Hierdie verskille bekragtig die genus as deel van die familie Camallanidae, maar dit is tog verwyderd genoeg om 'n aparte spesie te wees. Studies soos dié is belangrik omdat baie varswaterskilpaaie, tesame met hulle natuurlike parasiete, regoor die wêreld voorkom en as troeteldiere of voedsel gebruik word.

\section{Literatuurverwysings}

Baker, M.R., 1987, 'Rhabdias collaris n. sp.(Nematoda: Rhabdiasidae) from frogs of Tanzania', Systematic Parasitology, 9(3), 199.

Yeh, L-S, 1960, 'On a new filarioid worm, Edesonfilaria malayensis gen. et sp. nov. from the long-tailed macaque (Macaca irus)', Journal of Helminthology, 34(1-2), 125-128.

Martínez-Silvestre, A., Guinea, D., Ferrer, D. \& Pantchev, N., 2015, 'Parasitic enteritis associated with the Camallanid Nematode Serpinema microcephalus in wild invasive turtles (Trachemys, Pseudemys, Graptemys, and Ocadia) in Spain', Journal of Herpetological Medicine and Surgery, 25(1-2), 48-52.

Nota: 'n Seleksie van referaatopsommings: Studentesimposium in die Natuurwetenskappe, 25-26 Oktober 2018, SA Akademiegebou, Pretoria, Suid-Afrika. Gasredakteurs: Prof Rudi Pretorius (Departement Geografie, Universiteit van Suid-Afrika); Prof Chris Swanepoel (Departement Besluitkunde, Universiteit van Suid-Afrika); Me Andrea Lombard (Departement Geografie, Universiteit van Suid-Afrika) 